\title{
FOOD HABITS AND ULTRASTRUCTURE OF GASTRIC MILL OF THE GRAPSID CRAB, METOPOGRAPSUS MESSOR (FORSKAL, 1775) FROM THE RED SEA, EGYPT.
}

\begin{abstract}
Awaad A. El-Sayed*; Ali A. El-Meaddawy* and Fatma M. Fouda** *Zoology Department, Faculty of Science, Al-Azhar University, Nasr City, Cairo. **Zoology Department, Girls College for Arts, Sciences and Education, Ain Shams University, Cairo.
\end{abstract}

(Received:December 12, 1999)

Key Words: Grapsid crab, Metopograpsus messor, Red Sea.

\section{ABSTRACT}

uring the present study, the stomach contents of a medium-sized
grapsid crab, Metopograpsus messor (Grapsidae, Brachyura) inhabiting different habitats (rocky, sandy-rock, and mangrove swamps) of the Red Sea (southern Aqaba Gulf) were examined by both frequency occurrence and percentage points. The results show that this species is opportunistic omnivore, with general food items consisting of algae (brown, red, green and blue green), benthic animals dominated by crustacean copepods, isopods, amphipods and other crustaceans, in addition to foraminiferans, polychaetes and animal eggs, with few fragments of hydroids, bryzoans as well as organic debris and unidentified items. Higher plants including leaves and adventious roots of mangroves and seagrass leaves were also reported among stomach contents. Moreover, sediments were represented by considerable amounts at both different habitats and seasons. The types of foods were significantly different through various habitats and seasons.

The gastric mill of the crab, which deals mainly with mechanical digestion was investigated by both light and scanning electron microscopes. It appeared as a very complex structure, composed of 6 
ossicles arising as internal thickening and calcification of dorsal and postero-lateral walls of the cardiac stomach. These ossicles are pterocardiac, propyloric, exopyloric, urocardiac, zygocardiac and lateral ossicles. The first three ossicles are very simple and used mainly for articulation; while the latter ones are greatly modified with conspicuous enlargement, forming a mammalian-like teeth in zygocardiac ossicle, simple ridges and denticles in urocardiac one, or with many grooves and plates provided with dense hairs and accessory spines as in lateral ossicle. All these ossicles are well articulated together, working in a regular pattern adapted to chewing, grinding, and processing of ingested food.

\section{INTRODUCTION}

The medium-sized grapsid crab Metopograpsus messor (Forskal, 1775) (Grapsidae, Decapoda, Brachyura) is commonly found along the Red Sea coasts, living either in temporary burrows underneath stones, rock boulders and rubbles in both intertidal rocky and sandy-rock habitats, or in permanent burrows in muddy and mangrove swamps (Fisheison, 1971; Por et al., 1977; Vine, 1986; El-Sayed \& Hellal, 1995; El-Sayed, 1996a,b; Hellal et al., 1997). This Indo-West Pacific species is well distributed and very common along the Egyptian Red Sea Coasts, extending northwards in the Gulf of Suez and penetrating the southern limits of Suez Canal (Calman, 1927; Fox, 1927; Holthuis, 1956).

In spite of the abundance of Metopograpsus messor, this grapsid crab has no direct commercial value, but according to its distribution in intertidal zones, it plays, with other intertidal crabs, an important role in the general food chain, where many foraging fishes and other carnivorous marine animals such as octopuses and cuttlefish prey on it during high tide (Warner, 1977; Hill, 1979; Batoy et al., 1988) while many seabirds feed on it during low tide (Wamer, 1977; Beissinger, el al., 1988). 
Food habits and ultra structure of gastric mill of Metopograpsus messor from the Red Sea, Egypt

Several studies have been dealt with the taxonomy (Holthuis, 1977; El-Sayed \& Hellal, 1995), general distribution and abundance of grapsids inhabiting the different habitats at the Gulfs of Aqaba and Suez and the Red Sea proper (Holthuis, 1958; Fishelson, 1971; Vine, 1986; ElSayed 1996a,b). Also the status and abundance of $M$. messor is well known along the mangal ecosystem of South Sinai (Por et al., 1977; ElSayed 1996 a,b; Hellal et al., 1997). The reproductive biology of the Suez Guif population of this species had been treated by El-Sayed et al., (1998). In spite of the previous studies, little information about the general food habitat of grapsids in general and $M$. messor in particular and fine structure of gastric mill of this and other species is yet available.

This study aims to investigate the fine structure of gastric mill of this grapsid species and its relation to different food habits from different habitats of some Egyptian coasts of the Red Sea.

\section{MATERIALS AND METHODS}

Specimens of the present work were collected seasonaliy during the period from May 1997 to April 1998 from the Red Sea Coasts of South Sinai Protected Areas (Ras Mohammed and Nabq). Some specimens were collected from mangrove swamps at Nabq Area (E]Rewaisia, Al-Monqatea, and Al-Gharkana) and mangrove channel at Ras Mohammed and other specimens were collected from the rocky and sandy-rock beaches at Ras Mohammed (Aqaba beach, U-Landa, and Old Cave) and Nabq (Ras Atantour, Nakhlt Al Tal and southern entrance of the area).

Crabs were collected by hand from the intertidal rocky and sandy-rock habitats. A hand net were also used for rapidly running large individuals. Burrowing individuals in mangrove swamps were dug out. 
Collected crabs were preserved immediately in $10 \%$ formalin solution and kept in labelled plastic containers.

At the laboratory, crabs were sorted, sexed and weighed to the nearest $0.1 \mathrm{~g}$. Carapce width (C.W.) and carapace length (C.L.) were measured to the nearest $0.1 \mathrm{~mm}$ using a vernier caliper. Crabs were dissected, their stomachs were removed, cut longitudinally and all contents of cardiac portion were removed and weighed. The stomach contents were placed in divided petri-dishes, sorted and identified to specific level as possible using a binocular microscope (American Optical, Model 41). Frequency of occurrence and percentage points methods were used for stomach contents analysis according to Williams (1981). The general outline of the stomach was examined and drawn by a Camera lucida, and the gastric mills of individuals inhabiting different habitats were separated from stomach tissues examined and figured. The gastric teeth were counted under the binocular microscope. For the scanning electron microscopy, the gastric ossicles were washed in saline solution and preserved in $70 \%$ ethanol, then, the specimens were dehydrated in a series of ethanol and finally mounted on metal stubs, coated with gold in vacuum evaporator, examined, and photographed in AMRAY 1200, J SM-5400 SE.M. at National Radiation Research Center and Technology, Nasr City, Cairo.

\section{RESULTS}

\section{Food habits:}

The stomach contents of Metopograpsus messor collected from the different habitats of the Egyptian Coasts of the Gulf of Aqaba and Red Sea are presented in Table (1) and Figure (1). The investigation of these contents by both frequency occurrence and percentage points methods indicated that, this grapsid crab is opportunistic omnivore. That feeds on a wide variety of benthic organisms including algae (brown, green, red and blue green), and epifaunal animals such as polychaetes, copepods, 
Food habits and ultra structure of gastric mill of Metopograpsus messor

isopods, amphipods, foraminiferans, and occasionally hydroids and bryzoans, as well as dead fish and other decayed animals, in addition to higher plants particularly decomposed and fresh seagrass leaves, littoral leaves and adventious roots of mangroves. A considerable amount of sediments including sand grains and rock fragments were ingested with associated microbenthos.

It is remarkable from the data in Table (1) that, $M$. messor individuals can exploit the available natural resources in different habitats. However, sandy habitats were the poorest, and their food items consisted mostly of littoral isopods (including Eurydice arabica, Sphaeroma spp., and other unknown crustacean fragments and species) cryptic among the onshore washed algae and seagrasses (Table 1 and Fig. 1).

On the other hand, in rocky habitats (Aqaba beach at Ras Mohammed, and Ras Atantour at Nabq area), showed more variable food items for this crab with higher tendency towards herbivores, mainly different algae particularly during autumn (Table, 1 and Figs. $1 \& 2$ ). The brown algae including Sphacelaria spp., Sargassum sp., Cystoseira sp. represented 13.96 to $30.25 \%$ by point assessment during autumn and summer respectively. Blue green algae of different species, ranged from 6.88 during summer to $26.13 \%$ during autumn, followed by green algae (mostly Enteromorpha spp.), from 7.0 to $12.61 \%$ and finally red algae (mainly Polysiphonia spp., Laurencia sp., Gracilaria sp., Amphiroa sp., Jania sp., and others) which followed the same pattern of brown algae and accounted from 1.8 to $5.55 \%$ of food items (Fig. 2). Totally, the algal elements accounted $49.68 \%$ by point assessment during summer and increased up to $54.40 \%$ during autumn. In contrast, animal items were generally represented by low ratios, varying from $17.13 \%$ during autumn to $25.07 \%$ during summer. Crustaceans (copepods, isopods and amphipods) were the dominant, while foraminifrans were taken either within algae or among sediments (Fig. 2). 
In contrast, animals were the most dominant among food items of this crab in mangrove swamps (Table, 1) particularly during spring (varied collectively from $58.74 \%$ at Ras Mohammed to $64.56 \%$ at Nabq) with great tendency towards polychaetes ( 3.24 to $15.52 \%$ ) and isopods (19.38\%) as well as other benthic crustaceans (Fig. 2). However, during autumn, a tendency towards herbivorous habits was noticed, where high ratio of algae (39.14\%) as well as higher plants (19.15\%) were taken (Fig. 2).

Sediments were also represented by considerable values in different habitats. It varied from 19.60 to $26.71 \%$, (Table $1 \&$ Fig. 1 ), with relatively higher ratios in mangrove swamps (up to 43.47) during summer (Fig. 2). It may be taken either accidentally with food items such as algae in rocky habitats or scooped with blue green algae at mangrove swamps.

\section{Gastric mill:}

The digestive tract in Metopograpsus messor consists, as in many crabs, of foregut or stomodaeum (oseophagus and stomach), very short midgut and an extended hindgut or proctodaeum, with a pair of digestive glands (hepatopancreas) attached to the ventral side of midgnt. A pair of coiled intestinal caeca arises dorsally anterior to the begining of the hepatopancreatic ducts and another coiled one emerges also dorsally just anterior to the abdomen. The foregut occurs in the body cavity under the cardiac region of the carapace suspended by gastric muscles into the anterior end and ventral sides of the carapace. It starts with mouth opening on the ventral side, leading to a short vertical muscular oseophagus, which in turn opens to the ventral side of a sac-like structure, the stomach. As in most brachyurans, the stomach is distinctly divided into an anterior large portion called "cardiac stomach" and a small posterior one called "pyloric stomach" (Fig. 3a).

The present investigation using both light (binocular) and scanning electron microscopes showed that the gastric mill is well 
Food habits and ultra structure of gastric mill of Metopograpsus messor

developed and occupied the dorsal and postero-lateral sides of the cardiac stomach (Fig. 3b,c). Six ossicles were detected either with or without developed teeth and ridges. The urocardiac ossicle (Fig. 3b,c \& Plate Ia) is single and extends on the mid-dorsal surface of the cardiac stomach, flanked anteriorly with transverse, simple, pterocardiac ossicles (paired ossicle) and articulates posteriorly with a single, small, tetra-angular relative elongate plate, the propyloric ossicle (Fig. 3b,c \& Plate Ia). Both of pterocardiac and propyloric ossicles are without any teeth or ridges, while urocardiac ossicle is slightly sinking at mid-portion, forming a ventral granule at the middle but broadens gradually towards both the anterior and posterior ends, with 3 ridges on the ventral side of posterior end, that increase gradually towards articulation with the propyloric ossicle, forming the dorsal tooth (Plate 1a). A remarkable lateral denticle is also formed at each side just anterior to the origin of first ventral ridge (Plate Ia). A pair of dense brush hairs at the ventral sides of propyloric ossicle is found at the site of articulation with urocardiac ossicle (Plate Ia).

At the dorso-lateral sides of cardiac stomach, extend the zygocardiac ossicles (paired ossicle), which are triangular in shape (Plate Ib), articulate with the outer end of pterocardiac ossicle via its anterior slender portion and posteriorly with the exopyloric ossicle, which in turn attached dorsaily with the propyloric ossicle. The posterior portion of each zygocardiac ossicle is a massive, triangular structure, forming lateral tooth that is equiped with well developed transverse ridges which varied from 21 to 24 (Plate $\mathrm{Ib}$ ). These ridges are mammalian molar-like, which decrease gradually in size posteriorly, with lower entire edge and ending in smaller, posterior ridges with prominent process in upper side (Plate Ic). It is observed that the beginning of lateral teeth exactly facing the beginning of first ridge on the urocardiac ossicle. Also a dense tuft of a 
brush hairs was observed on the posterior portion of the lateral teeth, at the articulation with exopyloric ossicle (Plate Ib).

The lateral ossicles (paired) were also observed on the lateral side of the cardiac stomach. These articulate anteriorly with the pterocardiac ossicle lower to the junction of zygocardiac attachment (Fig. $3 c$ ) and extend postero-lateral on the inner side of zygocardiac ossicle forming an elongate ridge (Plate 1d) fringed inwards with dense hairs, and ending with an arch equiped with inward curved, calcified, exactly 13 accessory spines (Plate Ie). These spines are well separated from each other (Plate $1 \mathrm{f}$ ), and arising from a papillose cuticular surface (Plate IIa), covered with dense hairs in inner side and nearly 3 rows on outer side (Plate 1e).

Two lateral setose plates are extending vertically along the inner side of lateral ossicles (Plate Ib). They are form the posterior portion of the cardiac stomach. Each plate contains an elongate groove, fringed from the outer side with a strong and erect biplumose simple and compound hairs (Plate Ilb \& c). It extends from the ventral floor of the cardiac stomach to lateral press chamber of pyloric stomach, provided ventrally with an elongate hairs palp, arises at its base dense setulose hairs (Plate IIf). A vertical cardiac groove is formed between the ventrolateral setose plates, (Plate IIIa) with conspicous papillose cuticle (Plate IId \& e) and spiniform upper end (Plate IIIb). The latter groove leads to a complicated pyloric stomach, equiped with dense hairs and muscular wall (Plate, IIIce). The cardiac groove curves dorsally at its posterior end, forming the ventral cardiopyloric valve facing the dorsal cardiopyloric valve which together can separate the cardiac stomach from pyloric one (Fig. 3c).

\section{DISCUSSION}

The grapsid crab, Metopograpsus messor (Forskal, 1775) commonly occurs along the Red Sea coasts, particularly in the northern 
portion, but it decreases remarkably southwards (Vine, 1986). It is distributed successfly in the Gulfs of Suez and Aqaba (Monod, 1938; Holthuis, 1958, 1977; Fishelson, 1971; Por et al., 1977; El-Sayed \& Hellal, 1995; El-Sayed, 1996a,b) and extends northwards to the southern limits of the Suez Canal (Calman, 1927; Fox, 1927; Holthuis, 1956). This species inhabits mainly the upper littoral zones of rocky shores and sometimes occurrs in considerable numbers underneath stones and gravel in muddy and sandy - rock shores (El-Sayed et al., 1998). Moreover, it constructs permanent burrows in mangrove swamps and sometimes observed climbing mangrove trees and respiratory roots (Vine, 1986; ElSayed, 1996a,b; Hellal et al., 1997).

The present results showed that $M$. messor individuals can exploit all available natural resources in their different habitats. The food items of this species consists of a wide variety of benthic organisms including algae (brown, red, green and blue green), benthic invertebrates (crustaceans, foraminiferans, polychaetes, bryzoans, and hydroids), organic debris, fragments of higher plants (seagrasses, mangrove leaves and roots) as well as considerable amounts of sediments. In spite of its tendency towards herbivorous feeding habit in rocky habitats, a carnivorous habit is obvious in sandy habitats, where crustacean isopods were the main food items and omnivorous feeding habit is prevalent at mangrove sites, reflecting the abundance of these animals among mangrove swamps.

The previous studies indicated that most members of Grapsidae are herbivorous (Warner, 1977; Grahamme, 1983; Giddins, et al., 1986). Warner (1977) mentioned that a little grapsid crab, Sesarma ricordi living on the Carribbean strandline in tidal mangroves feeds mostly on vegatation washed up by the tide and also eats carrion as well as any small animals (insects, amphipods and worms). So it is omnivorous and classified as specialized generalists, while Aratus pisonii is a mangrove 
leaves eater, but Goniopsis is omnivore, feeding on mangrove mud, dead leaves, mangrove seeds, seagrasses and small animals. On the other hand, Neosarmatium smithi and Gecarcoidea sp. feed on rotting roots of mangrove and carrions but considered herbivores (Warner, 1977; Giddins et al., 1986). In contrast, Jones (1984) mentioned that $M$. messor in mangrove swamps is omnivores and its food reflects its significant role in controlling the structure and succession of mangrove swamps and so recycling their organic matter by feeding on leaves and new growths which accord with Smith and Kitching (1988), Steinke èt al., (1993), Dahdouh-Guebas et al. (1998) and Lee (1998).

Moreover, a wide range of micro-organisms have been recorded from the sediments taken by deposit feeding mangal crabs. Most authors considered bacteria, ciliates, algae and nematods to be the principal items extracted from the sediments (Jones, 1984;Robertson, 1986).

Percentage points showed that the food of $M$. messor is seasonally controlled. Algae were increased significantly during autumn and summer, while animals showed the reverse and increased during spring. This variation is correlated with fluctuations in temperature and consequently blooming of benthic biota. Choy (1986) mentioned that, algae were eaten during late spring and early autumn, during which, nutrient values such as proteins are high due to high density of epiphytes on macro-algae. Mantelatto and Petracco (1997) mentioned that the amount of food items decreased seasonally in the following order: autumn $>$ summer $>$ winter $>$ spring for the calappid crab, Hepatus pudibundus.

The structure of $M$. messor gastric mill is very complicated consisting of 6 articulated ossicles. Although, the main function of these ossicles collectively concerned with chewing, grinding and tituration of ingested food (Warner, 1977; Holdish \& Reeve, 1988) there is a specific specilization in the function of each ossicle alone. The pterocardiac, propyloric and exopyloric ossicles are simple, without teeth, denticles, or 
ridges and used only for articulation between other massive and well modified ossicles and gastric muscles. The urocardiac, and zygocardiac ossicles are strong and have well developed teeth and ridges. The lateral ossicle has, in addition to strong accessory spines, many ridges and palps, provided with various hairs either simple or with associated setules.

It is obvious that, this structure enables $M$. messor individuals to deal with different types of food in different habitats. However, the structure of this gastric mill indicates the phylogenitic origin of M. messor towards the herbivory feeding habit. Warner (1977) had discussed the different types of gastric mills in crabs, and concluded that well developed denticles and ridges found on dorsal and lateral teeth of vascular plant eater and herbivorous crabs, become less developed in omnivores and deposit feeder crabs, but spiniform teeth characterized the gastric mills of carnivorous crabs.

The present results are very similar to those recorded by Giddins et al. (1986) on Neosarmatium smithi feeding on mangrove leaves. The scanning electron micgraphs showed that lateral teeth have heavily dentate ridges which interlock with those on dorsal tooth. Also, a number of curved spines that meet together over dorsal tooth are visible on lateral teeth possibly used for keeping food in place. Similar gastric mills were previously described for mangrove crabs Aratus pisonii and Ucides cordatus (Warner, 1977), and in other crabs with alternative feeding habits (Warner, 1977; Giddins et al., 1986).

The chewing mechanism was previously described in both crabs (Warner, 1977) and crayfishes (Holdich \& Reeve, 1988). This mechanism involves the contraction and subsequent relaxation of anterior and posterior gastric muscles (extrinsic muscles) as well as intrinsic gastric muscles and by elasticity of gastric cuticle which lead to elongate the cardiac stomach, moving the dorsal tooth downwards and forwards in an arc between the latcral teeth. This helps grinding and crushing any food 
between them, while food moves within stomach from place to place with the help of intrinsic muscle contraction and relaxation.

The setose margins of the ventrolateral cardiac plate form an effective barrier to the entry of all but small particles and fluid (Holdich \& Reeve, 1988). The fine particulate food passes through the ventrolateral plate into the pyloric stomach by pushing via the dorsal tooth. The digested food enters the ducts of hepatopancreas from the ventral pyloric filter chamber, while indigestible matter and waste materiais are passed through the ventral cardiac groove to the upper side of pyloric stomach to be egested through hindgut (Warner, 1977; Holdich \& Reeve 1988) after being bound within a peritrophic membrane secreted from midgut diverticulum (Holdich \& Reeve, 1988).

\section{REFERENCES}

Batoy, C.B.; Pilapil, B.C. \& Sarmago, J.F. (1988): Size composition, length-weight relationship and natural food of the blue crab, Portunus pelagicus (L.) in selected coastal waters in Leyte and vicinity Philippines. An. Tro. Res. (Philippines), 10 (3):177-182.

Beissinger, S.R; Thomas, B.T. \& Strahl, S.D. (1988): Vocalizations food habits and nesting biology of the slender-billed kite with comparisons to the snail kite. Wilson - Bull., 100(4):604-616.

Calman, W.T. (1927): Report on the Crustacea Decapoda (Brachyura). Zoological Results of the Cambridge Expedition to the Suez Canal, 1924, XIII. Trans. Zool. Soc. Lond., Vol. 22, pp. 211-217. 
Food habits and ultra structure of gastric mill of Metopograpsus messor from the Red Sea, Egypt

Choy, S.C. (1986): Natural diet and feeding habits of the crabs Liocarcinus puber and L. holsatus (Decapoda, Brachyura, Portunidae). Mar. Ecol. Prog. Ser. 31:87-99.

Dahdouh - Guebas, F.; Veneirt, M.; Tack, J.F.; Speybroeck, D-Van, Koedam, N.; \& Van-Speybroeck, D. (1998): Propagule predators in Kenyan mangroves and their possible effect on regeneration. Mar. Freshwat. Res., 49(4):345-350.

El-Sayed, A.A.M. \& Hellal, A.M. (1995): Grapsid crabs (family Grapsidae : Crustacea) of the Egyptian Coast of the Red Sea AlAzhar Bull. Sci., 6(2):1843-1858.

El-Sayed, A.A.M. (1996a): Brachyuran crabs of South Sinai Coasts, Gulf of Aqaba, Red sea, Egypt. Al-Azhar Bull. Sci., 7(1):685-698.

El-Sayed, A.A.M. (1996b): The horizontal zonation of brachyuran crabs in the shallow water coasts of the northern Red Sea and Gulf of Aqaba, South Sinai, Egypt. J. Fac. Educ. Ain Shams University, 21:221-235.

El-Sayed, A.A.M.; Saber, S.A.; El-Damhougy, K.A. \& Fouda, M.M.A. (1998): The reproductive biology of grapsid crab, Metopograpsus messor (Forskal, 1775) from Ain Sukhna, Gulf of Suez. Egypt. J. Aquat. Biol., Fish., 2(4):359-377.

Fishelson, L. (1971): Ecology and distribution of the benthic fauna in the shallow waters of the Red Sea. Mar. Biol., 10:113-133.

Fox, H.M. (1927): Appendix to the Report on the Crustacea Decapoda (Brachyura). Zoological Results of the Cambridge Expedition to the Suez Canal, 1924. XIII Trans. Zool. Soc. Lond., Vol. 22, pp. 217-219.

Giddins, R.L.; Lucas, J.S.; Neilson, M.J. \& Richards, G.N. (1986): Feeding ecology of the mangrove crab, Neosarmatium smithi 
(Crustacea : Decapoda, Sesarmidae). Mar. Ecol. Prog. Ser. 33:147-155.

Grahame, J. (1983): Adaptive aspects of feeding mechanisms. In : The Biology of Crustacea. Vol. 8:65-107. Academic Press, Inc.

Hellal, A.M.; El-Sayed, A.A.M. \& Abu Zeid, M.M. (1997): The macroinvertebrate fauna of Nabq mangal area, Wadi Kid, South Sinai, Egypt. Al-Azhar Bull. Sci., 8(l):205-222.

Hill, B.J. (1979): The biology of the crab, Scylla serrata in the St. Lucia, South Africa. Trans. R. Soc. S. Afr., 44(1):55-62.

Holdich, D.M. \& Reeve, I.D. (1988): Functional morphology and anatomy. In : Freshwater crayfish biology, management and exploitation. (Holdich, D.M. \& Lowery, R.S., eds. Groom Helm, Timber Press 21-51.

Holthuis, L.B. (1956): Notes on a collection of Crustacea Decapoda from the Great Bitter Lake, Egypt, with a list of the species of Decapoda known from the Suez Canal. Zool. Meded. Leiden, 34 (22):301-330.

Holthuis, L.B. (1958): Crustacea Decapoda from the northern Red Sea (Gulf of Aqaba and Sinai Peninsula). Hippidea and Brachyura (Dromiacea, Oxystomata, and Grapsoidea). II. Contributions to the knowledge of the Red Sea. No. 9, Haifa Bull. Sea Fisheries Res. Sta., Vol. 17:41-54.

Holthuis, L.B. (1977): The Grapsidae, Gecarcinidae and Palicidae (Crustacea, Decapoda, Brachyura) of the Red Sea. Isr. J. Zool. 26:141-192.

Jones, D.A. (1984): Crabs of the mangal ecosystem. In : Hydrobiology of the mangal (Por, F.D. \& Dor, I., Eds). The Hague : Dr. W. Junk Publishers. The Hauge, 84-109. 
Food habits and ultra structure of gastric mill of Metopograpsus messar from the Red Sea, Egypt

Lee, S.Y. (1998): Ecological role of grapsid crabs in mangrove ecosystems : A review. Mar. Freshwat. Res., 49(4):335-343.

Mantelatto, F.L.M. and Petracco, M. (1997): Natural diet of the crab Hepatus pudibundus (Brachyura : Calappidae) in Fortaleza Bay, Ubatuba (sp), Brazil. J. Crust. Biol., 17(3): 440-446.

Monod, T. (1938): Decapoda Brachyura. In : Mission Robert Ph. Dollfus en Egypte. VIII. Mem. Inst. Egypte, 37:91-162.

Por, F.D.; Dor, I. \& Amir, A. (1977): The mangal of Sinai. Limits of an ecosystem. Helg. Wiss. Meeresunt, 30:295-314.

Robertson, A.I. (1986): Leaf-burying crabs: their influence on energy flow and export from mixed mangrove forests (Rhizophora spp.) in northeastern Australia. J. Exp. Mar. Biol. Ecol., 102:237-248.

Smith, T.J. III \& Kitching, R.L. (1988): The influence of seed predators on structure and succession in tropical tidal forests. Proc. Ecol. Soc. Aust., 15:203-211.

Steinke, T.D.; Rajh, A. \& Holland, A.J. (1993): The feeding behaviour of the red mangrove crab Sesarma meinerti de Man 1887 (Crustacea : Decapoda : Grapsidae) and its effect on the degradation of mangrove leaf litter. South Af. J. Mar. Sci., 13:151-160.

Vine, P. (1986): Crustacea. In : Red Sea Invertebrates. pp. 95-216. IMMEL Publishing.

Warner, G.F. (1977): The Biology of Crustacea. Elek Science London, pp. 202.

Williams, M.J. (1981): Methods for analysis of natural diet in Portunid crabs (Crustacea, Decapoda, Portunidac). J. Exp. Mar. Biol. Ecol., 52:103-113. 
Table 1. The general food items of Metopograpsus messor collected from different habitats of the South Sinai Coasts, Red Sea.

\begin{tabular}{|c|c|c|c|c|c|c|}
\hline \multirow{2}{*}{$\begin{array}{l}\text { Habitats } \\
\text { Food categories }\end{array}$} & \multicolumn{2}{|c|}{ Mangroves } & \multicolumn{2}{|c|}{ Rocky } & \multicolumn{2}{|c|}{ Sandy rock } \\
\hline & $\% \mathrm{~F}$ & $\% \mathrm{P}$ & $\% \mathrm{~F}$ & $\% \mathrm{P}$ & $\% \mathrm{~F}$ & $\% \mathrm{P}$ \\
\hline - Plants & & 26.27 & & 59.17 & & \\
\hline - Algae & -- & 15.03 & & 57.60 & -- & -- \\
\hline - Brown & 44.4 & 4.42 & 50.0 & 20.74 & -- & -- \\
\hline - Red & 27.8 & 4.21 & 37.5 & 6.32 & -- & -- \\
\hline - Green & 11.1 & 2.61 & 37.5 & 10.33 & -- & -- \\
\hline - Blue green & 22.2 & 3.79 & 50.0 & 20.21 & -- & -- \\
\hline - Higher plants & & 11.24 & & 1.57 & & \\
\hline - Mangrove leaves & 27.8 & 5.08 & - & -- & -- & -- \\
\hline $\begin{array}{l}\text { Mangrove adv. } \\
\text { Roots }\end{array}$ & 27.8 & 1.90 & -- & - & -- & -- \\
\hline - Seagrass leaves & 5.6 & 4.26 & 12.5 & 1.57 & -- & -- \\
\hline - Animals & & 47.02 & & 16.33 & & 80.36 \\
\hline - Copepods & 16.7 & 0.21 & 25.0 & 0.93 & 20.0 & 3.57 \\
\hline - Amphipods & 16.7 & 0.19 & 12.5 & 10.12 & 20.0 & 3.57 \\
\hline - Isopods & 5.6 & 3.39 & -- & - & 20.0 & 55.36 \\
\hline fragments & 44.4 & 10.87 & 25.0 & 1.46 & 20.0 & 17.86 \\
\hline - Animal eggs & 11.1 & 0.27 & 12.5 & 0.52 & & \\
\hline - Polychaetes & 22.2 & 1.34 & -- & -- & -- & -- \\
\hline - Bryzoans & 27.8 & 4.55 & 12.5 & 0.14 & -- & -- \\
\hline - Foraminiferans & 61.1 & 1.81 & 37.5 & 0.66 & -- & -- \\
\hline - Hydroids & 5.6 & 0.68 & -- & -- & -- & -- \\
\hline - Digested U.K. & 33.3 & 11.39 & 12.5 & 0.79 & - & -- \\
\hline - Organic debris & 22.2 & 8.32 & 37.5 & 4.71 & -- & -- \\
\hline -Sediments & & 26.71 & & 25.50 & & 19.64 \\
\hline - Sand grains & 66.7 & 13.21 & 100.0 & 14.03 & 20.0 & 10.00 \\
\hline - Rock fragments & 66.7 & 13.50 & 100.0 & 10.47 & 20.0 & 9.14 \\
\hline
\end{tabular}

$\% \mathrm{~F}=$ Frequency occurrence; $\% \mathrm{P}=$ Percentage points; U.K.=Digested unidentified animals 
Food habits and ultra structure of gastric mill of metopograpsus messor from the Red Sea, Egypt

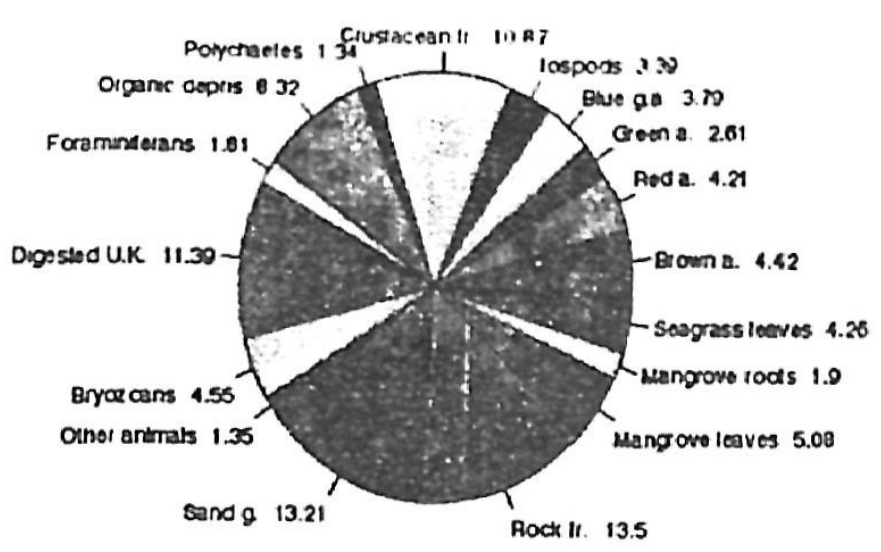

Mangroves

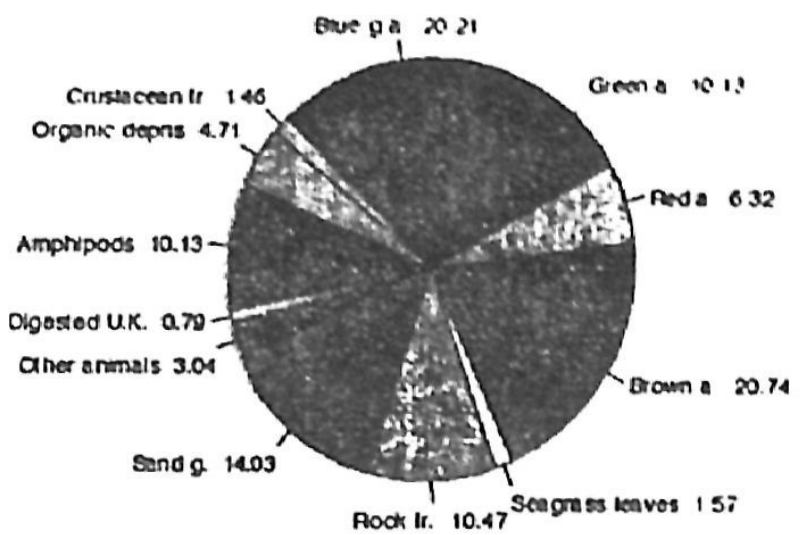

Rocky habitats

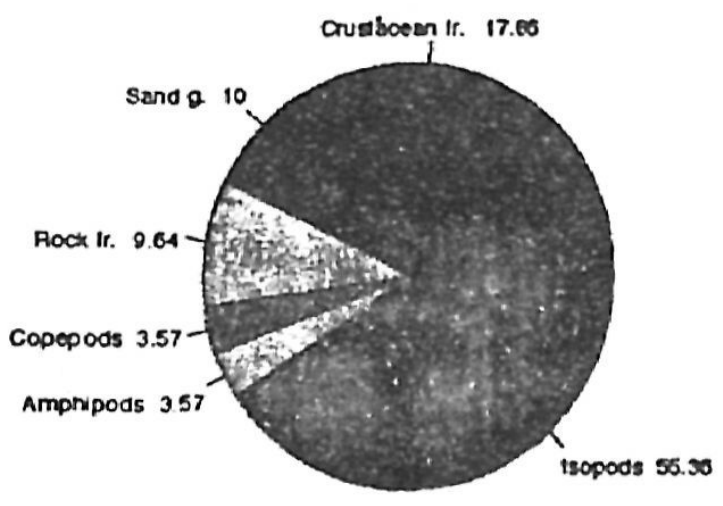

Sand habitats

Figure (1): Seasonal fluctuations in food items of Metopograpsus messor. in different habitats (notes : $\mathrm{a}=$ algae, $g . \mathrm{a}=$ green algae, $\mathrm{f} \mathrm{r}=$ fragments, $g=$ grains). 


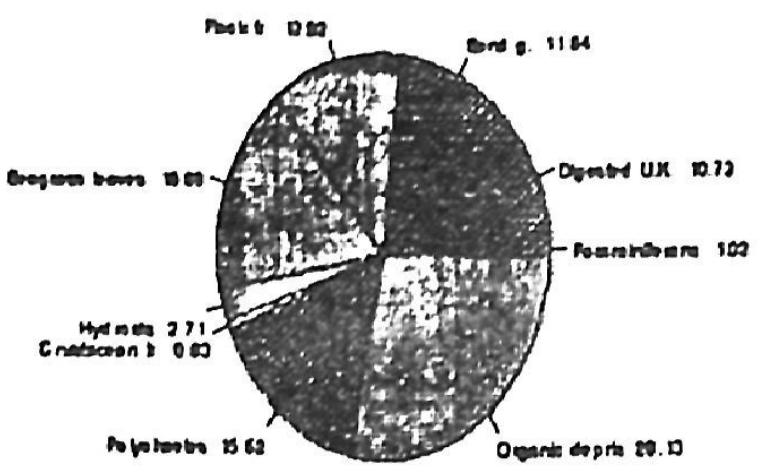

Spring (Pas Mohammed, mangroves)

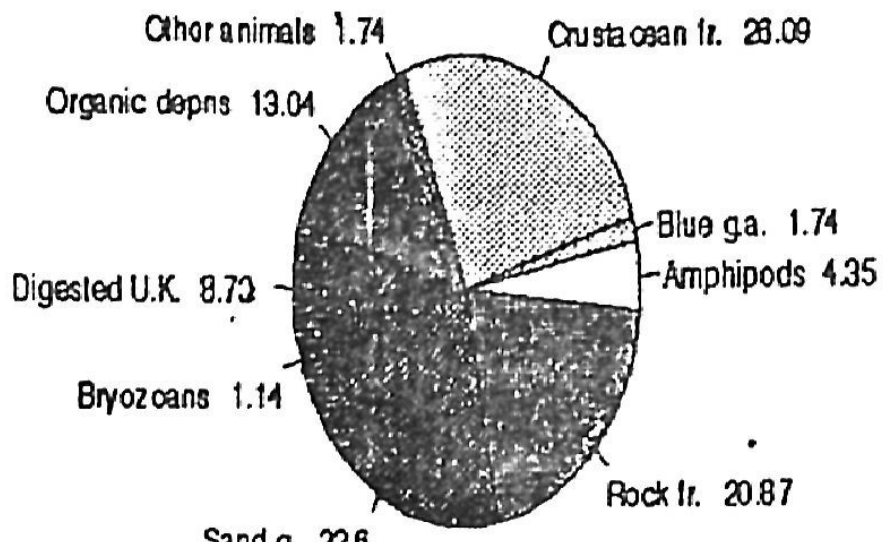

Summer(Mangroves Ras Mohammed)

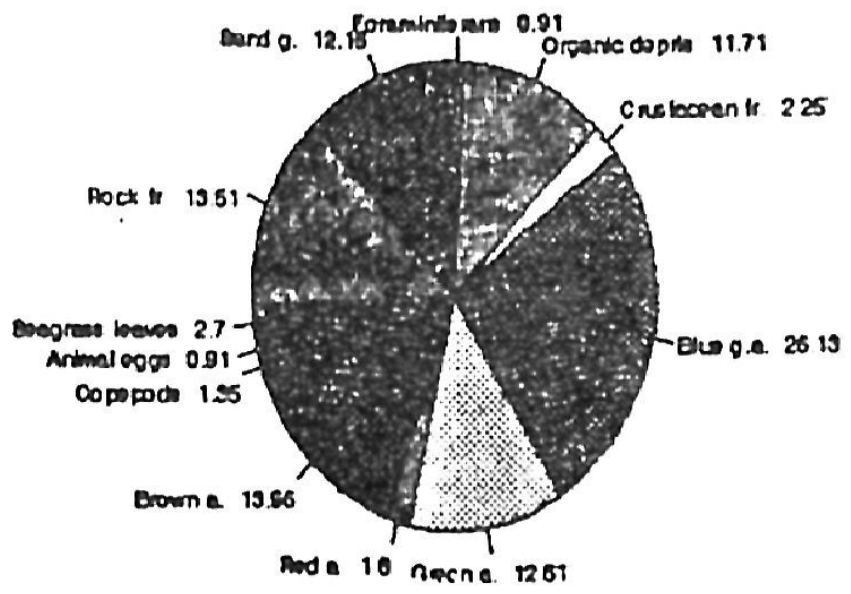

Autumn (Ras Monemmed, rocky habilds)

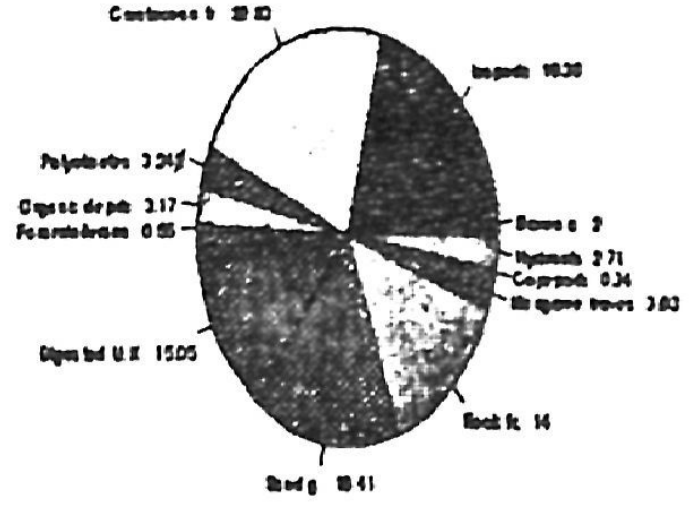

Spring (Mabq, margroves)

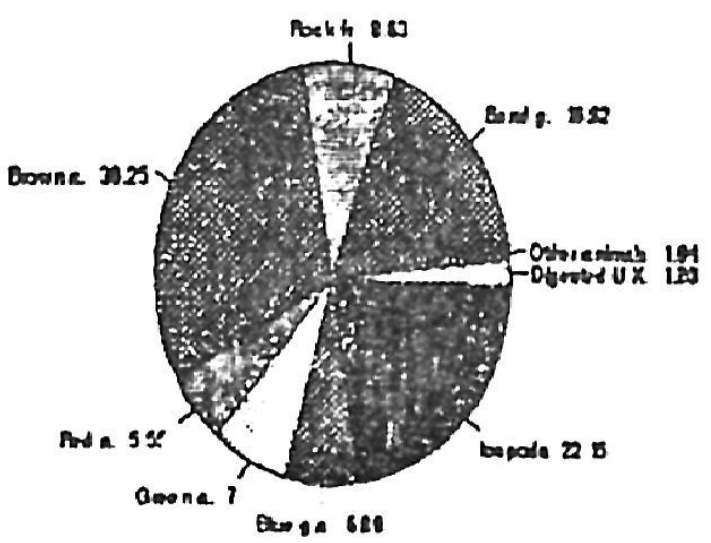

Summer (Nabq. rocky habthate)

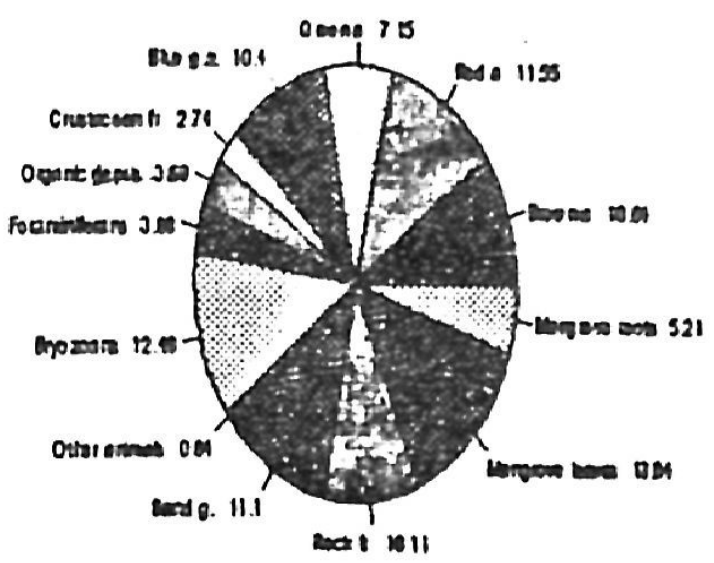

Auturnn (Nabq, mangrover)

Figure (2): The general food items of Mfetopograpsus messor from mangrove sivamps, rocky and sandy habitats of the Red Sea ( $a=$ algac, $f r=$ fragments, $g=$ grains, u.k. $=$ unkmown). 


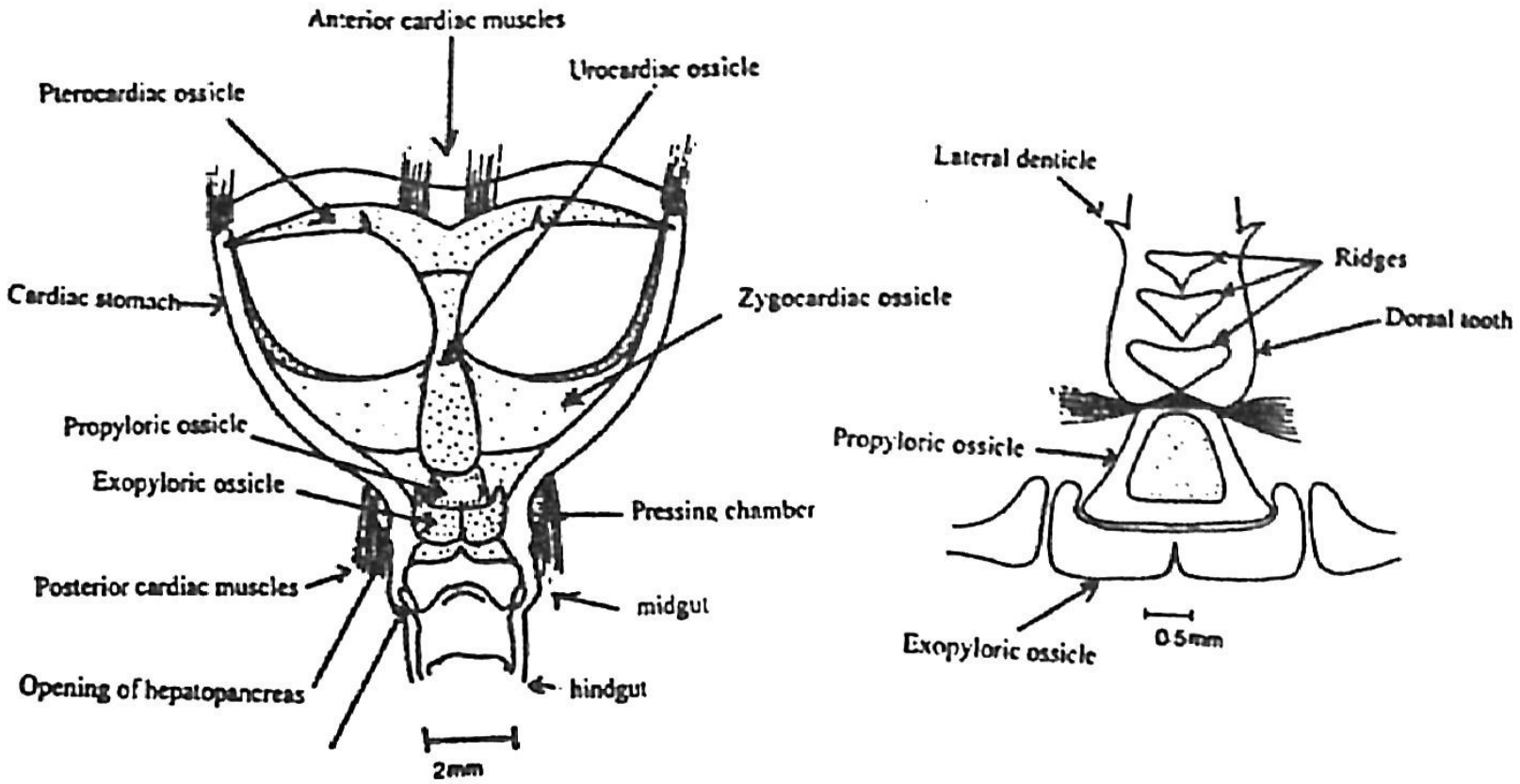

A

B

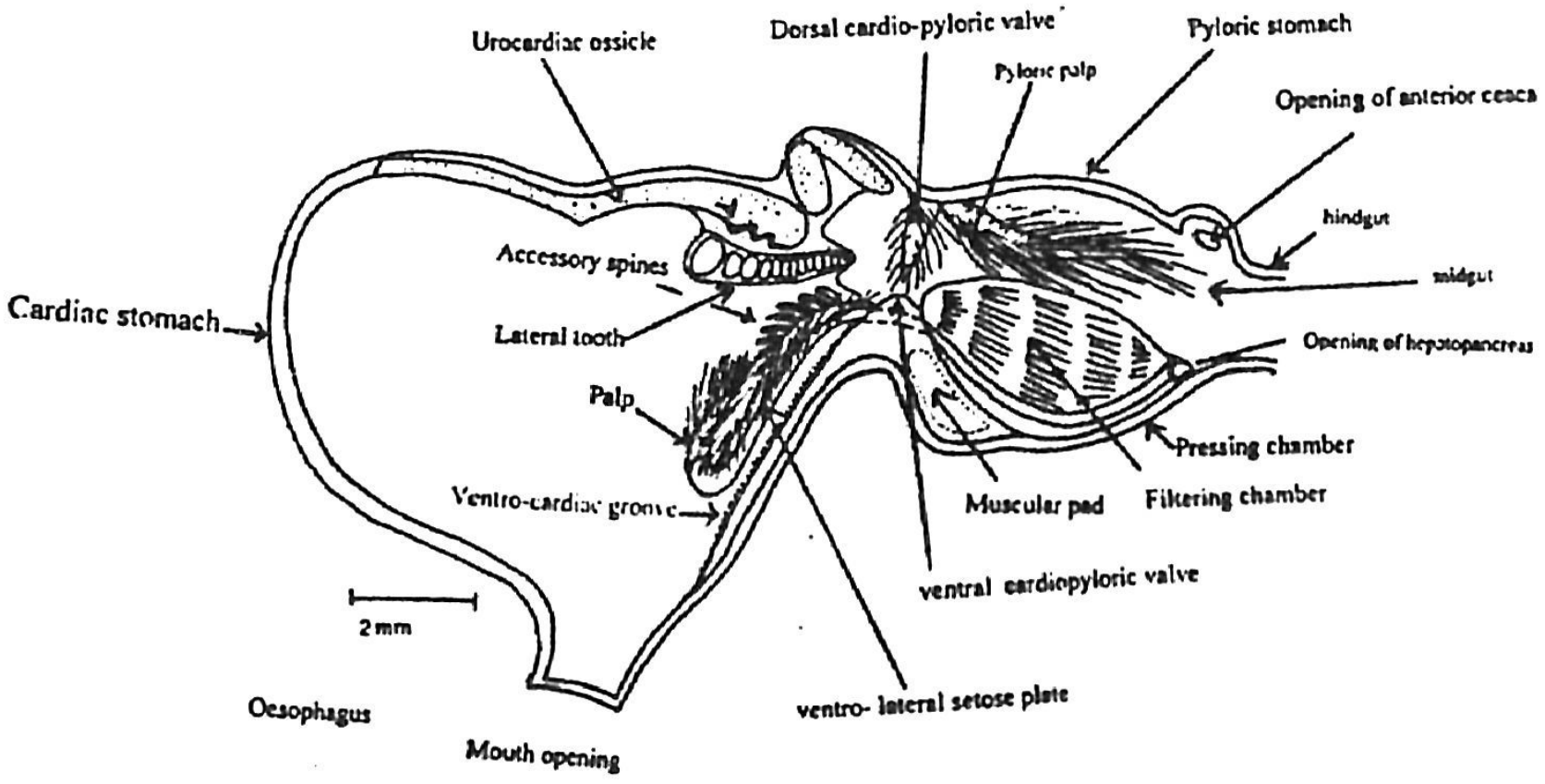

C

Figure (3): Diagrammatic representation for the stomach of Metopograpsus messor showing different parts and gastric mill, (a) dorsal view of the stomach, (b) ventral view of the dorsal tooth, and (c) side view of th.e stomach. 


\section{EXPLANATION OF PLATES}

Plate (I): Scanning electron micrographs for gastric mill of Metopograpsus messor showing: (a) dorsal tooth of urocardiac ossicle with tooth's ridges (t.r), hairs (h.), articulation with propyloric ossicle (p.o) and lateral denticle (1.d), of dorsal tooth; (b) lateral tooth of zygocardiac ossicle with large denticles (d) and ridges (r); (c) enlarged upper border of lateral tooth (notes the presence of small dorsal processes (pr.) on posterior ridges and obtus face of large denticle (d.); (d) outer surface of lateral ossicle with inward thickned ridge equiped with calcified accessory spines (c.a.s); (e) calcified accessory spines (notes dense hairs in inner rim and fewer ones on outer rim. (f) enlarged portion of cuticle showing cuticular surface and origin of accessory spines.

Plate (II): Scanning electron micrographs showing the morphology of gastric mill of Metopograpsus messor: (a) high magnification of cuticular surface of lateral ossicle at arising of calcified accessory spines; (b) ventrolateral setose plate (v.s.) of lateral ossicle with biplumose hairs (h); (c) enlarged biplumose hairs of ventrolateral plate; (d) ventrolateral setose plate with palp (p.), accessory spines (a.s.), ventro-cardiac groove (v.c.g.) and papillose cuticle (p.c.); (e) enlarged papilose cuticle cardiac groove; (f) especialized hairs of lateral palp.

Plate (III): Scanning electron micrographs of the gastric mill of Metopograpsus messor showing: (a) cardiac groove (c.g); (b) spiniform (s.) posterior end of cardiac groove; (c) pyloric stomach with muscular wall and pressing pyloric chamber (p.p.ch.); (d) enlarged pyloric stomach showing pressing chamber (p.ch.), posterior pyloric chamber (p.p.ch.), filtering chamber (f.ch.) and muscular wall; (e) inner features of pressing chamber showing heavily dense hairs. 


\section{Plate I}

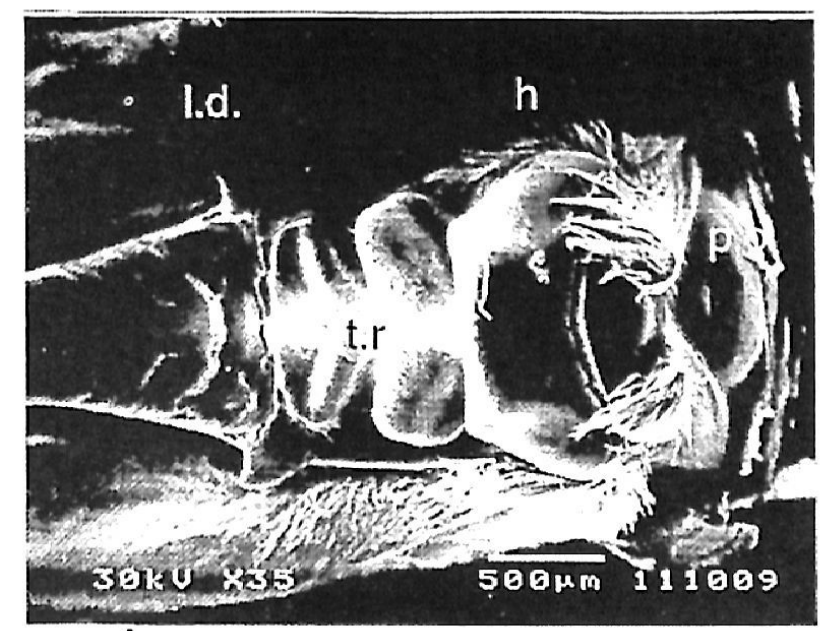

A
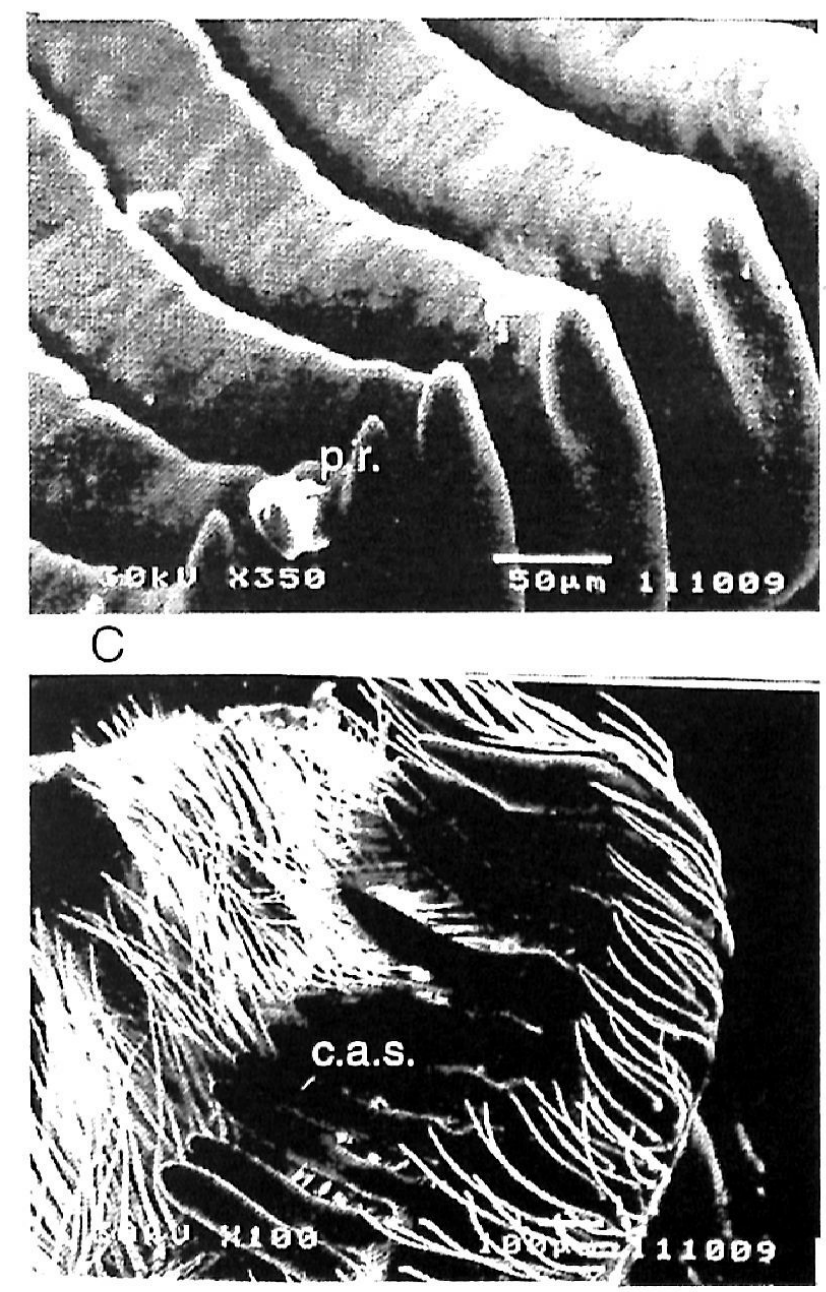

E
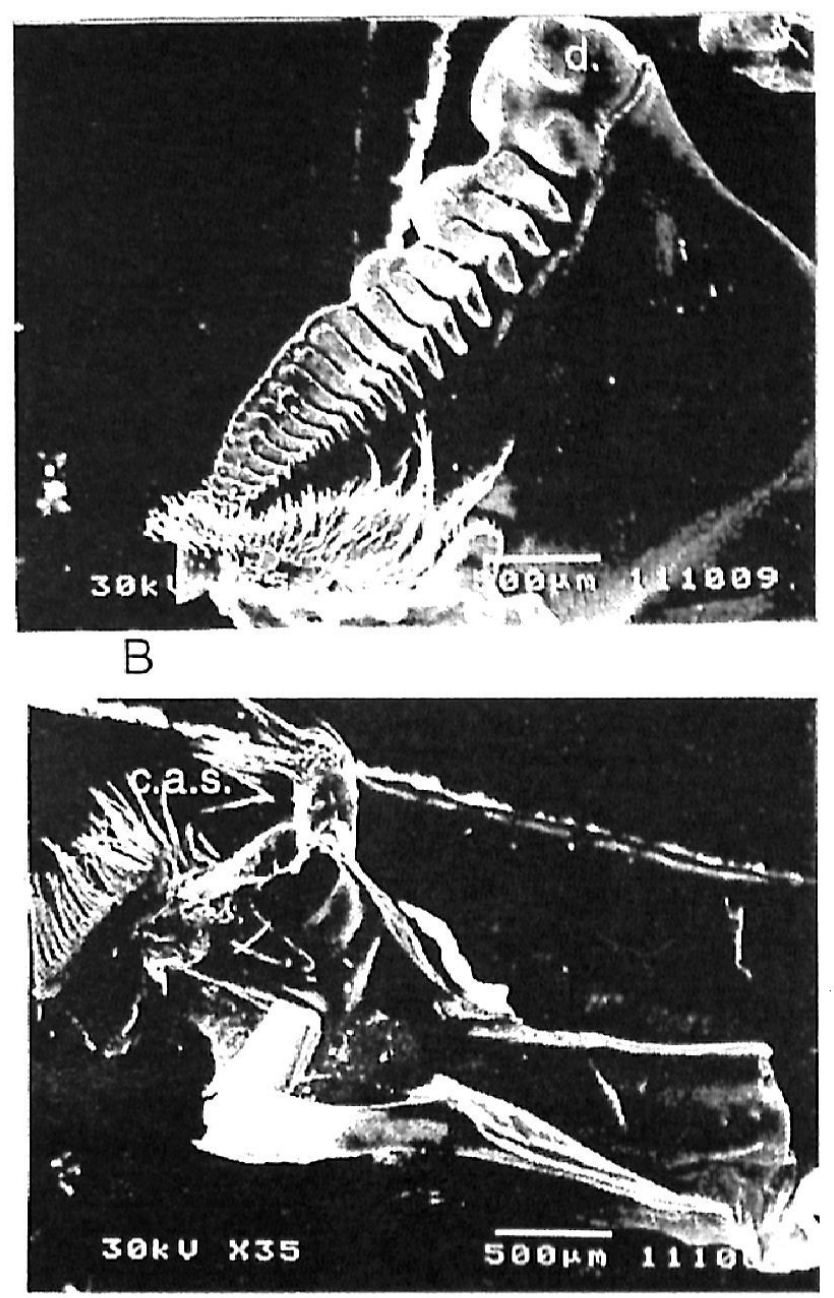

D

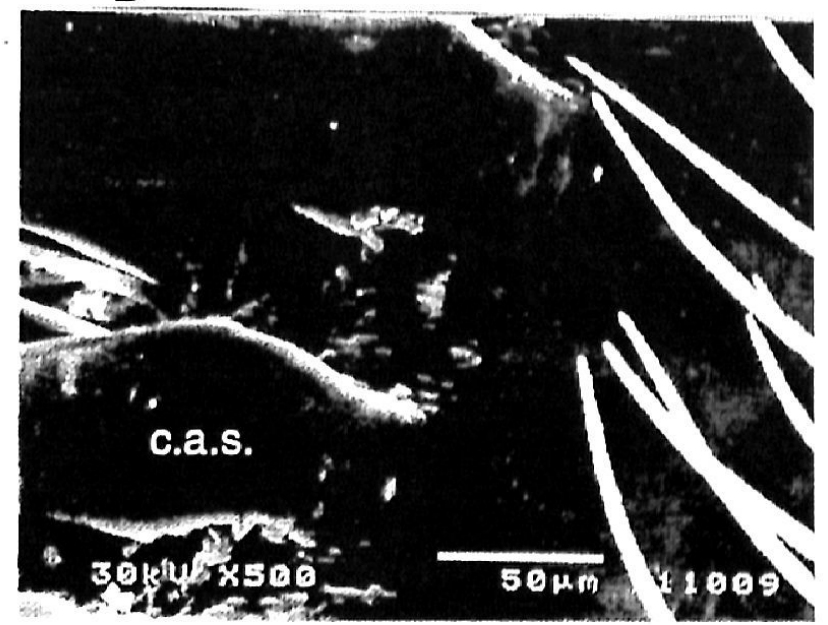

F 


\section{Plate II}

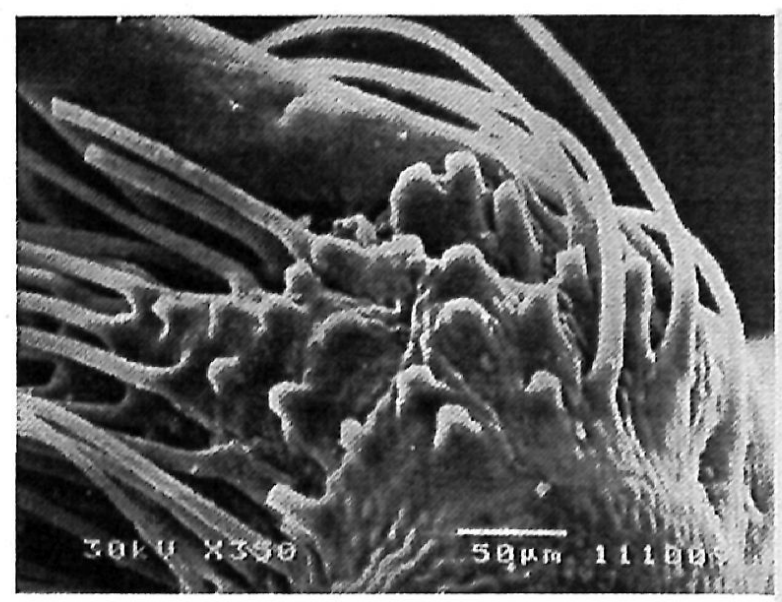

A

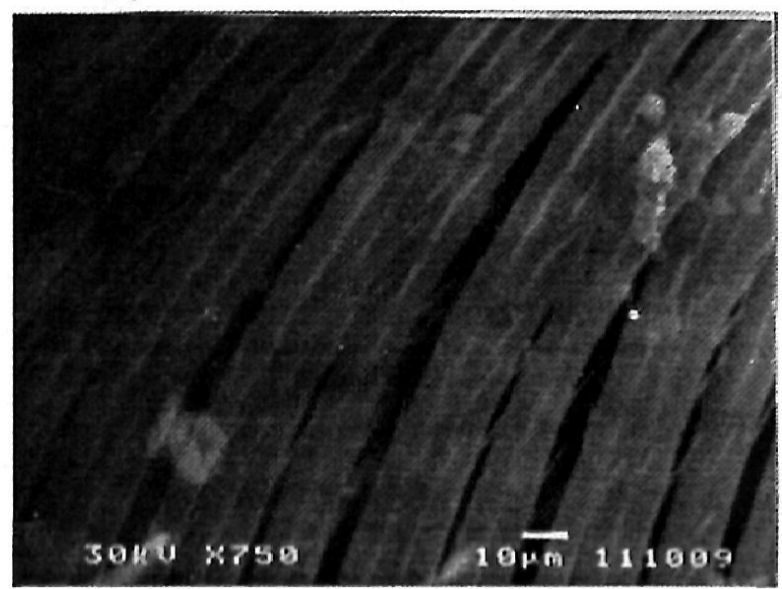

C

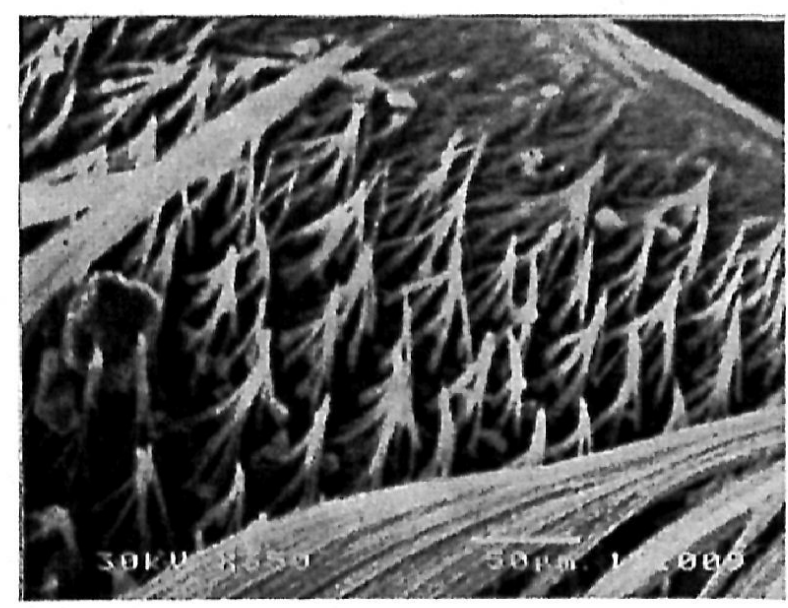

E

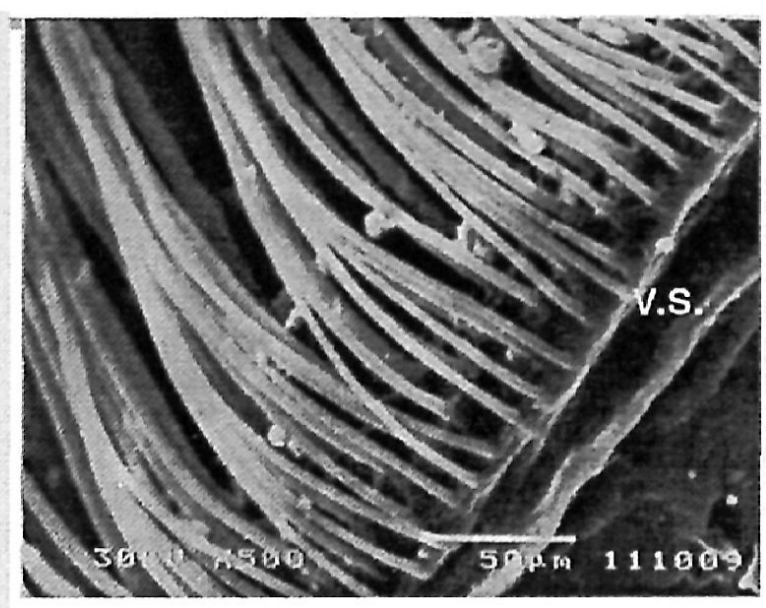

B

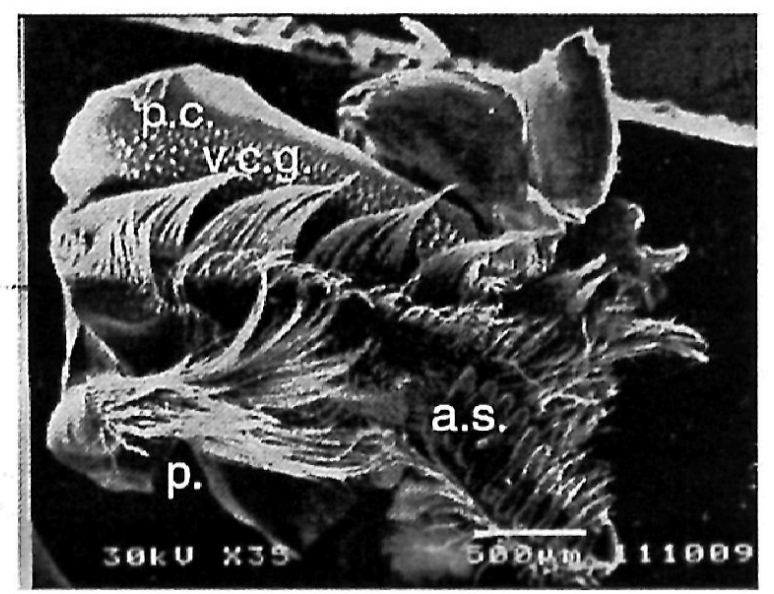

D

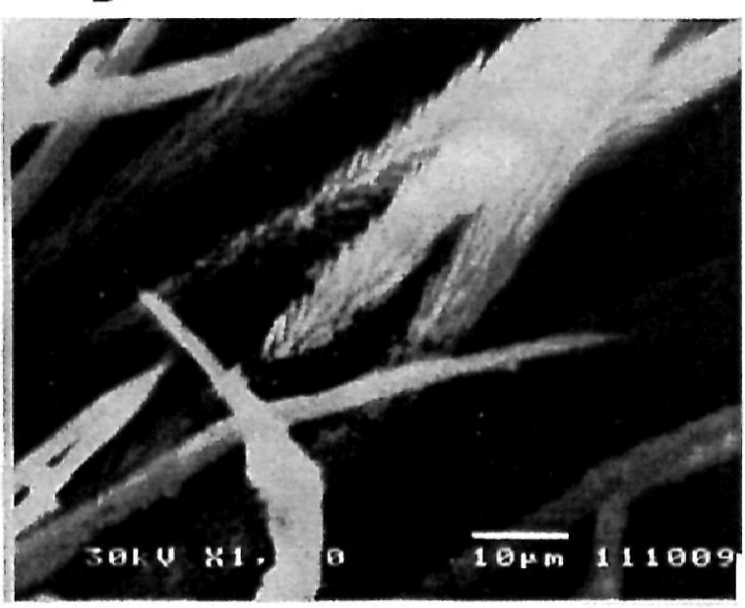

F 


\section{Plate III}

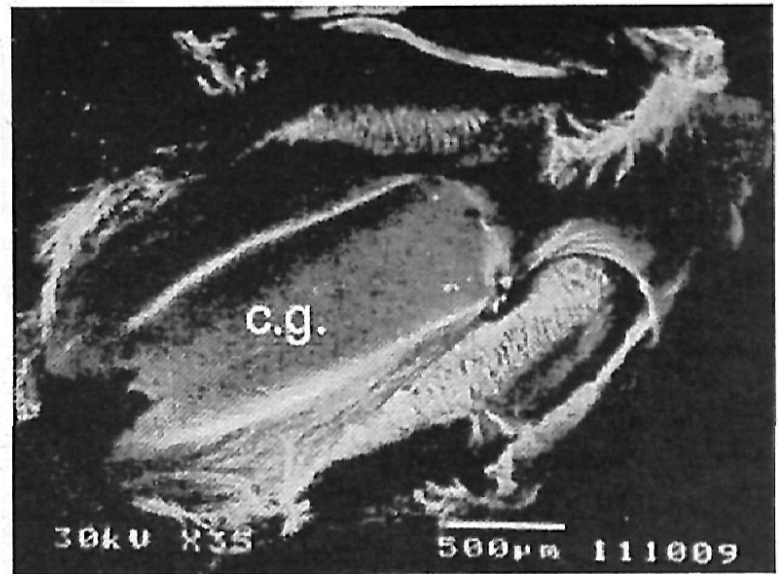

A

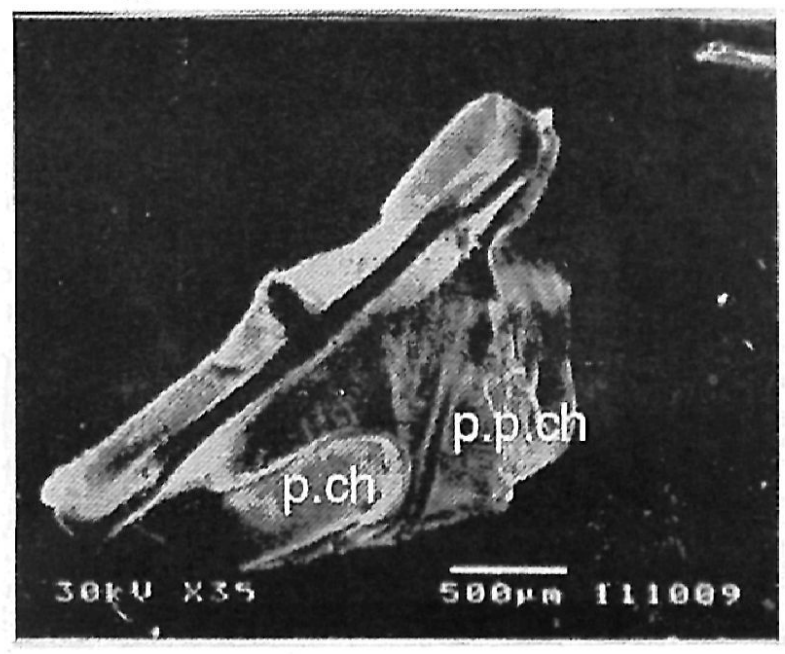

C
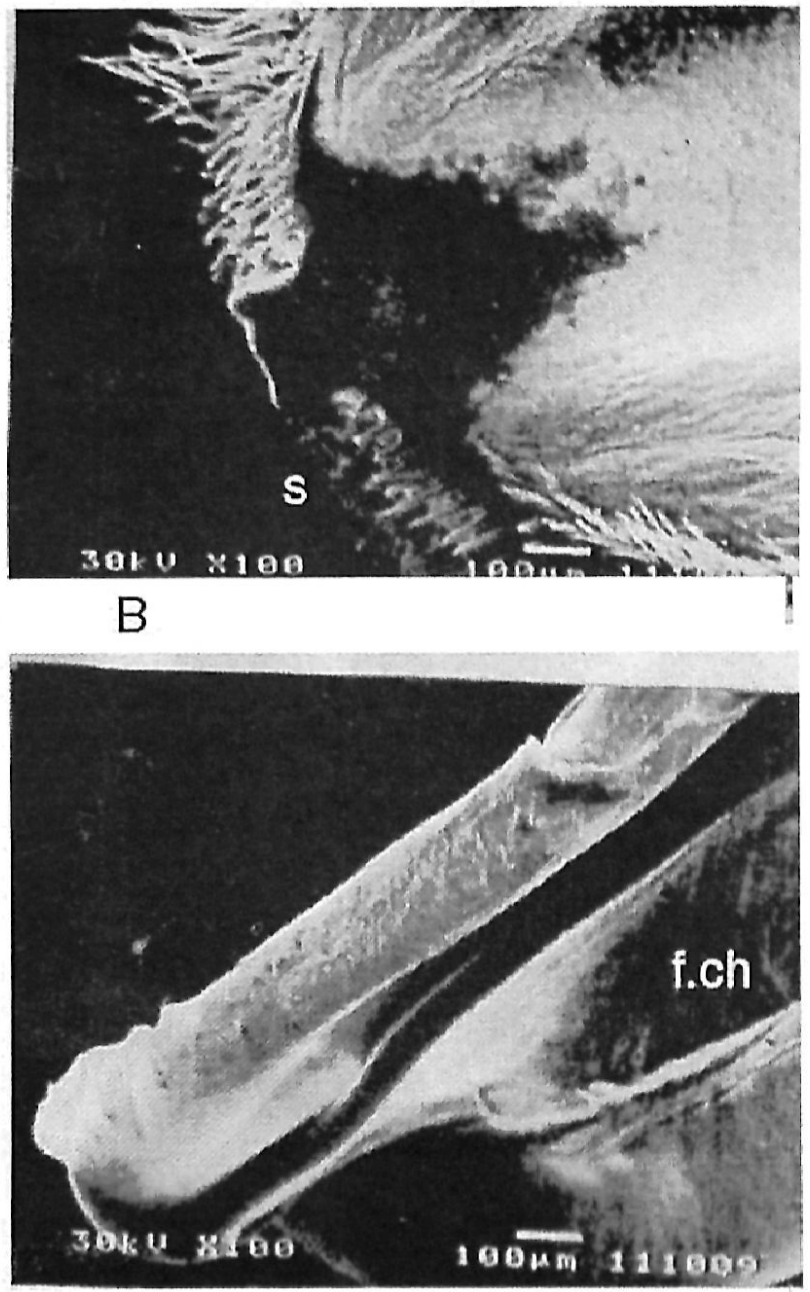

D

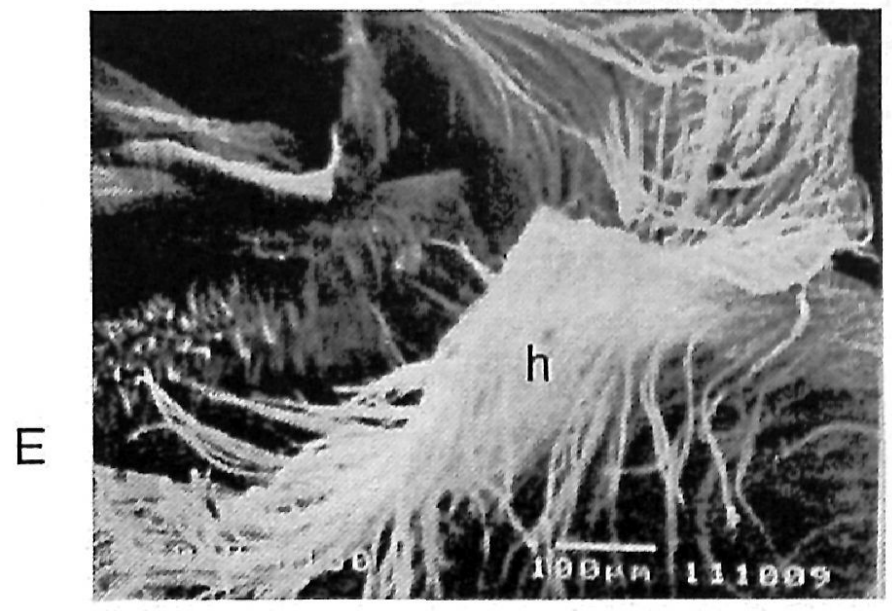

